\title{
Hydrurus foetidus (Chrysophyceae): an update and request for observations
}

\section{Dag Klaveness}

Department of Biological Sciences, University of Oslo, 0316 Oslo, Norway

Hydrurus foetidus is a cold-water golden alga (Chrysophyceae) found in fast-flowing rivers mainly during time of snowmelt. It has primarily been studied by scientists located near alpine or northern locations, but there are also observations both in south and north America, Russia, Japan, in the Hope Bay area (Antarctica) and Himalaya. If and where environmental conditions are appropriate, Hydrurus may be distributed "worldwide." More information is wanted from areas where its presence may be expected.

Key Words: chrysophyceae; distribution; Hydrurus; morphology; psychrophile; rheophile

Hydrurus foetidus (Villars) Trevisan is visibly a large freshwater alga found in cold rivers. The chrysophytes are better known by their planktonic members, like the colonial Chrysosphaerella or the loricate Dinobryon. In general, freshwater chrysophytes are associated with softwater lakes, also common in dilute brown-water ponds (Wehr et al. 2015). But Hydrurus is a rheophile, preferring swiftly flowing water (Traaen and Lindstrøm 1983, Raven 1992, Rott et al. 2006a). It is also a psychrophile (sensu Cavicchioli 2016), dependent on low temperature. $\mathrm{Hy}$ drurus appears to be of specific importance for the early emerging aquatic larvae of chironomids (e.g., Ward 1994, Niedrist and Füreder 2018 and references therein).

Hydrurus thrives well under seasonal climatic conditions, where there is snow in the winter, cold meltwater and moderate summer temperatures. Its early emergence at time of snowmelt makes it visually prominentbut it can be overlooked by scientists unless they know what to look for, when and where to sample and how to recognize it (e.g., Rott et al. 2006a, 2006b, Klaveness 2017, Fig. 2). As winter declines and insolation and daytime in- creases, Hydrurus may be the first alga visually present through the water scope. Depending upon local stream conditions and other factors still to be studied, the thalli may be richly branched (Klaveness et al. 2011) or only a central axis densely covered by small branchlets (due to "sehr starke Strömung" according to Bursa 1934, I, p. 76). Rostafiński (1882) made exact artistic representations of details and variability of this species-here reproduced as Fig. 1. Examination of samples by light microscopy (Fig. 2) reveals characteristic details, discerning Hydrurus from the emerging algal competitors. When photos of specimens sampled at different locations are compared, variants of morphological organization may be seen. More samples, more cultures and further investigations by experiments and genetic methods are required to resolve questions about phenotypic plasticity, ecotypes or species identity (cf. the genus and species in http://www. algaebase.org).

The abiotic and biotic environments from where the samples were taken should be recorded-as has been done in Austria particularly (e.g., Geitler 1927, Kann terms of the Creative Commons Attribution Non-Commercial License (http://creativecommons.org/licenses/by-nc/3.0/) which permits unrestricted non-commercial use, distribution, and reproduction in any medium, provided the original work is properly cited.
Received October 4, 2018, Accepted January 15, 2019

* Corresponding Author

E-mail: dag.klaveness@ibv.uio.no Tel: +47-47-261-197 


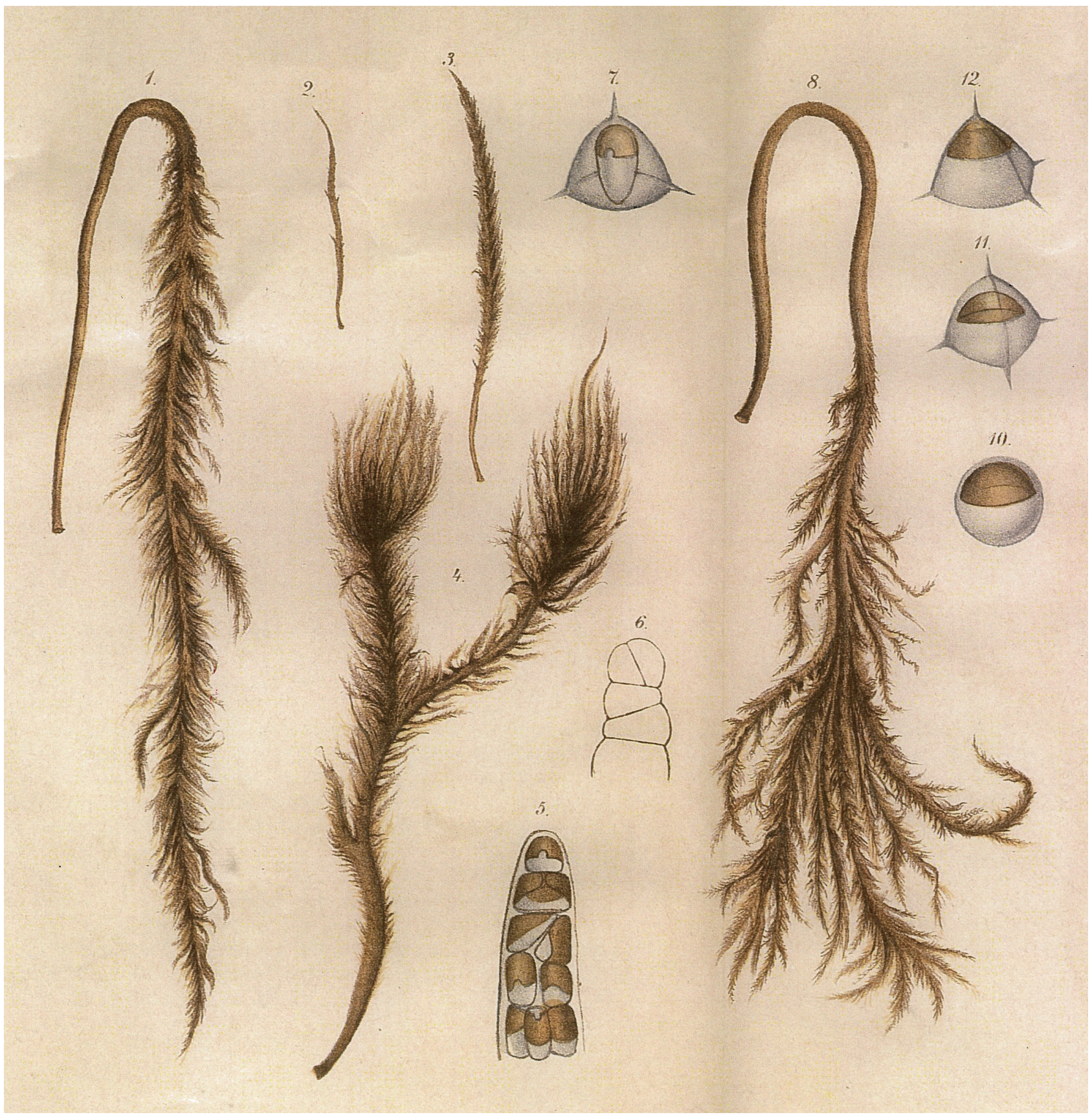

Fig. 1. Growth forms and details of branch apex and tetraedal spores of Hydrurus as drawn by Rostafiński (1882, part of Tab.II). The thalli, from the smallest growth form to the larger branched specimens are admirably drawn. The tetrahedral spores are less detailed and are drawn without the emerging flagellum. For photographs and sizes, see Klaveness et al. (2011). [Colour figure can be viewed at http://www.e-algae.org].

1978, Rott and Wehr 2016 and references therein), in Norway (Lindstrøm et al. 2004, Remias et al. 2013, Rott and Schneider 2014), recently in Croatia (Koletić et al. 2017), and the classical investigations in the Tatra mountains in Poland (Rostafiński 1882, Bursa 1934, Kawecka 1989, 1993, 2003a, 2003b).
Regional surveys have shown that Hydrurus foetidus is not found in every river that may be a suitable habitat (Geitler 1927, Bursa 1934, Parker et al. 1973). Detailed studies of the rivers in the Polish Tatra (Bursa 1934, I, pp. 70-74 and 1934, II, with discussion) have revealed the temperature sensitivity of this species. An optimal range 


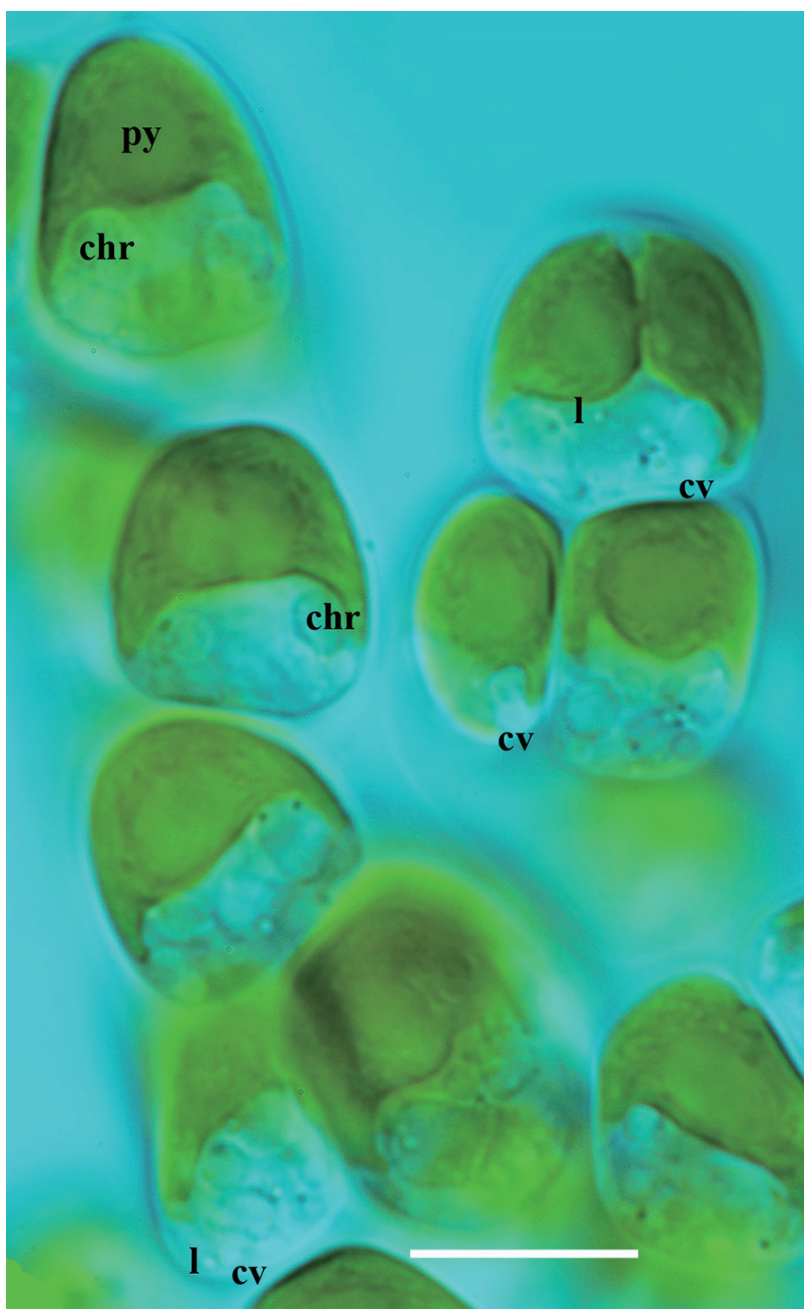

Fig. 2. Characteristic cells of Hydrurus in a growing thallus, embedded in their polysaccharide sheath (not visible). At top, left, is the apical cell of an emerging branch. At apex, in the direction of growth, is the chloroplast with a pyrenoid (py). On both sides, below the chloroplast, are two large chrysolaminarine (chr) vesicles visible, one is marked here and one in the cell below. In each cell, there are more than two of these vesicles. The top cell at right shows a longitudinal shallow trench at the surface of the chloroplast. A tiny lipid vesicle (I) is in focus, as well as a larger contractile vacuole (cv) at work. There are more than one contractile vacuoles in each cell, often two or three, all located basally in each cell. They are good indicators of life at the microscope stage. The cell nucleus is barely visible in living cells, it is located in the cell center close to the chloroplast. For more details, see photographs in Klaveness (2017). Scale bar respresents: $10 \mu \mathrm{m}$. [Colour figure can be viewed at http://www. e-algae.org].

for Hydrurus in this area is given as $2-12^{\circ} \mathrm{C}$, whilst higher temperature may only be tolerated for a very limited time (hours). Bursa (1934) established that Hydrurus could perish in lower ranges of rivers during the summer and therefore needed to be reintroduced from colder ranges of the river system-at higher elevations in glacial rivers, or closer to the source (cold springs) in rivers of krenal origin. Bursa (1934) distinguished between the permanent and the temporal ranges of rivers-where the lower limits of Hydrurus populations would fluctuate from year to year (Hydrurus "wanderungen”). Kann (1978) studied the entire communities of algae in her rivers, and only in "summer-cold" ranges found permanent communities of Hydrurus. Whereas, Hydrurus located in lower regions (summer-warm) might only support short-lived spring populations. In general, possible summer survival may be limited to resting stages (silicified stomatocysts), to palmellae, or to shredded central axes at shielded locations in the river, as thalli may fragment and disappear under these conditions (also noted by Canter-Lund and Lund 1995). Under moderate seasonal climates, Hydrurus may have a visible or conspicuous reappearance early in the autumn (e.g., in Austria: Kann 1978, Rott et al. 2000; in Norway: Lindstrøm et al. 2004; in Croatia: Koletić et al. 2017). It may be present through autumn and winter in some glacial streams in Switzerland (Uehlinger et al. 2010) and in the United States (Hoffman et al. 1986). During winter, Hydrurus may survive as "amorphic" (Kann 1978), while Rostafiński (1882, separatum p. 33) and again Bursa (1934) find persistent forms of Hydrurus during winter in some Tatra mountain river ranges. The waxing and waning of Hydrurus in permanent locations, or its spatio-temporal development, may be affected by seasonal or yearly challenges as flooding, nutrient availability, competition, parasitism, and grazing-often in combination with the variability of temperature and light conditions (Kann 1978, Kawecka 1989, 1993, 2003a, 2003b, Rott et al. 2006a, 2006b, Robinson et al. 2010, Rott and Wehr 2016).

When assembling and studying the printed contributions about Hydrurus foetidus, we find an apparent limit of distribution to outside of an approximate $40^{\circ} \mathrm{N}$ to $40^{\circ} \mathrm{S}$ belt around equator. Ward (1994) referred to the distribution of Hydrurus as holarctic, which also should include some cold temperate inland localities (as a high-mountain location in east Turkey at $39^{\circ} 44^{\prime} \mathrm{N}$ ) (Çevik et al. 2007). The most apparent exceptions to the distribution limits suggested above are the very high mountain observations in Nepal and Tibet / China (e.g., Hirano 1969, Subba Raju and Suxena 1979). Our preliminary conclusions are influenced by lack of observed sightings near to the $40^{\circ} \mathrm{N}$ latitude in south-east Asia as well as in alpine areas in the south Americas where there are positive records at $41^{\circ} \mathrm{S}$ (e.g., Villanueva et al. 2010).

The long-lasting winters in both South and North Korea due to areas and elevations permitting snow in abun- 
dance, makes a closer look into rivers to be of interest. As mentioned above, the summer temperature in rivers may be limiting to distribution. Among the closest published records of Hydrurus populations to Korea are in northern Japan (e.g., Kobayasi 1961, Fukushima 1962, Hara and Shitara 2009) or Russia (Primorsky region by Gontcharov 1996, Rudnaya river by Barinova et al. 2008). Observations from North Korea would increase the probability of many positive records. Korean scientists are, by this note, encouraged to visit rivers at times of snowmelt, observe, and if possible establish and study new cultures of this unique chrysophyte, since, to my knowledge, my culture is still the only one in existance. See Klaveness (2017) for environmental and culture conditions.

\section{ACKNOWLEDGEMENTS}

The investigations were supported by the AKVA group at Department of Biological Sciences, University of Oslo, who provided cold-room culture facilities. The author is indebted to the personnel at Finse Alpine Research Centre (www.finse.uio.no), who supported the initial isolation of Hydrurus. The author is grateful to senior scientist Eli-Anne Lindstrøm from Norwegian Institute of Water Research (NIVA) who provided literature, and to Mrs. Janet Jacobsen who corrected the language.

\section{REFERENCES}

Barinova, S., Medvedeva, L. \& Nevo, E. 2008. Regional influences on algal biodiversity in two polluted rivers of Eurasia (Rudnaya River, Russia, and Qishon River, Israel) by bioindication and canonical correspondence analysis. Appl. Ecol. Environ. Res. 6:29-59.

Bursa, A. 1934. Hydrurus foetidus Kirch. w Polskich Tatrach. - Hydrurus foetidus Kirch. in der Polnischen Tatra. I. Oekologie, Morphologie. II. Phenologie. Bull. Int. Acad. Pol. Sci. Lett. Cl. Sci. Math. Nat. Sér. B Sci. Nat. I:69-84.

Canter-Lund, H. \& Lund, J. W. G. 1995. Freshwater algae: their microscopic world explored. Biopress Ltd., Bristol, $360 \mathrm{pp}$.

Cavicchioli, R. 2016. On the concept of a psychrophile. ISME J. 10:793-795.

Çevik, F., Whitton, B. A. \& Öztürk, O. 2007. A new genus record for the freshwater algal flora of Turkey. Turk. J. Bot. 31:149-152.

Fukushima, H. 1962. Preliminary report on the life history of Hydrurus foetidus. Acta Phytotax. Geobot. 20:290-295 (in Japanese, with English summary).

Geitler, L. 1927. Über Vegetationsfarbungen in Bächen. Biologia Generalis. Internationale Zeitschrift für die allgemeinen Fragen der Lebensforschung. Band III. Emil Hain \& Co., Wien und Leipzig and The John Hopkins Press, Baltimore, MD, pp. 791-814.

Gontcharov, A. A. 1996. The algal flora of the Primorsky Region, Russian Far East. Hydrobiologia 336:93-97.

Hara, Y. \& Shitara, T. 2009. A newly recognized higher taxon of chrysophycean algae: 114. Phycologia 48:40.

Hirano, M. 1969. Freshwater algae from Rangtang Himal, Nepal Himalaya. Contrib. Biol. Lab. Kyoto Univ. 22:1-42.

Hoffman, L. R., Vesk, M. \& Pickett-Heaps, J. D. 1986. The cytology and ultrastructure of zoospores of Hydrurus foetidus (Chrysophyceae). Nord. J. Bot. 6:105-122.

Kann, E. 1978. Systematik und Ökologie der Algen der österreichischer Bergbäche. Arch. Hydrobiol. Suppl. 53:405643.

Kawecka, B. 1989. Sessile algal communities in a mountain stream in conditions of light gradation during its flow through a cave (West Tatra, Poland). Acta Hydrobiol. 31:35-42

Kawecka, B. 1993. Ecological characteristics of sessile algal communities in streams flowing from the Tatra Mountains in the area of Zakopane (Southern Poland) with special considerations of their requirements with regard to nutrients. Acta Hydrobiol. 35:295-306.

Kawecka, B. 2003a. Effect of different light conditions on cyanobacteria and algal communities in Tatra Mts stream (Poland). Oceanol. Hydrobiol. Stud. 32:3-13.

Kawecka, B. 2003b. Response to drying of cyanobacteria and algae communities in Tatra Mts stream (Poland). Oceanol. Hydrobiol. Stud. 32:27-38.

Klaveness, D. 2017. Hydrurus foetidus (Chrysophyceae): an inland macroalga with potential. J. Appl. Phycol. 29:1485-1491.

Klaveness, D., Bråte, J., Patil, V., Shalchian-Tabrizi, K., Kluge, R., Gislerød, H. R. \& Jakobsen, K. S. 2011. The 18S and 28S rDNA identity and phylogeny of the common lotic chrysophyte Hydrurus foetidus. Eur. J. Phycol. 46:282291.

Kobayasi, H. 1961. Chlorophyll content in sessile algal community of Japanese mountain river. Bot. Mag. Tokyo 74:228-235.

Koletić, N., Alegro, A., Šegota, V., Vuković, N., Rimac, A. \& Vilović, T. 2017. New sites of rare cold-water golden algae Hydrurus foetidus (Villars) Trevisan (Ochrophyta: Chrysophyceae) in Croatia. Nat. Croat. 26:305-311.

Lindstrøm, E. -A., Johansen, S. W. \& Saloranta, T. 2004. Periphyton in running waters: long-term studies of natural 
variation. Hydrobiologia 521:63-86.

Niedrist, G. H. \& Füreder, L. 2018. When the going gets tough, the tough get going: the enigma of survival strategies in harsh glacial stream environments. Freshw. Biol. 63:1260-1272.

Parker, B. C., Samsel, G. L. Jr. \& Prescott, G. W. 1973. Comparison of microhabitats of macroscopic subalpine stream algae. Am. Midl. Nat. 90:143-153.

Raven, J. A. 1992. How benthic macroalgae cope with flowing freshwater: resource acquisition and retention. J. Phycol. 28:133-146.

Remias, D., Jost, S., Boenigk, J., Wastian, J. \& Lütz, C. 2013. Hydrurus-related golden algae (Chrysophyceae) cause yellow snow in polar summer snowfields. Phycol. Res. 61:277-285.

Robinson, C. T., Kawecka, B., Füreder, L. \& Peter, A. 2010. Biodiversity of flora and fauna in alpine waters. In Bundi, U. (Ed.) The Handbook of Environmental Chemistry. Vol. 6. Alpine Waters. Springer-Verlag, Berlin, pp. 193-223.

Rostafiński, J. 1882. Hydrurus i jego pokrewieństwo. Monografia. Rozprawy i Sprawozdania z Posiedzeń Wydziału Matematyczno-Przyrodniezego Akademii Umiejętności. Vol. 10. Nakł. Akademii, Krakow, pp. 60-86 (separatum pp. 1-29, RÉSUMÉ. Hydrurus und seine Verwandschaft. Eine Monographie, separatum pp. 31-34).

Rott, E., Cantonati, M., Füreder, L. \& Pfister, P. 2006a. Benthic algae in high altitude streams of the Alps: a neglected component of the aquatic biota. Hydrobiologia 562:195-216.

Rott, E., Füreder, L., Schütz, C., Sonntag, B. \&Wille, A. $2006 b$. A conceptual model for niche differentiation of biota within an extreme stream microhabitat. Verh. Int. Verein Limnol. 29:2321-2323.
Rott, E. \& Schneider, S. C. 2014. A comparison of ecological optima of soft-bodied benthic algae in Norwegian and Austrian rivers and consequences for river monitoring in Europe. Sci. Total Environ. 475:180-186.

Rott, E., Walser, L. \& Kegele, M. 2000. Ecophysiological aspects of macroalgal seasonality in a gravel stream in the Alps (River Isar, Austria). Verh. Int. Verein Limnol. 27:1622-1625.

Rott, E. \&Wehr, J. D. 2016. The spatio-temporal development of macroalgae in rivers. In Necchi, O. Jr. (Ed.) River Algae. Springer International Publishing, Basel, pp. 159-195.

Subba Raju, N. \& Suxena, M. R. 1979. Algae and Testaceae of the Cho Oyu (Himalayas) expedition-II: Cyanophyta, Chlorophyta, Euglenophyta, Chrysophyta and Testacea. Hydrobiologia 67:141-160.

Traaen, T. S. \& Lindstrøm, E. -A. 1983. Influence of current velocity on periphyton distribution. In Wetzel, R. G. (Ed.) Periphyton of Freshwater Ecosystems. Developments in Hydrobiology. Vol. 17. Springer, Dordrecht, pp. 97-99.

Uehlinger, U., Robinson, C. T., Hieber, M. \& Zah, R. 2010. The physico-chemical habitat template for periphyton in alpine glacial streams under a changing climate. Hydrobiologia 657:107-121.

Villanueva, V. D., Buria, L. \& Albariño, R. 2010. Primary consumers and resources: annual variation in two contrasting reaches of a Patagonian mountain stream. Ann. Limnol. Int. J. Limnol. 46:21-28.

Ward, J. V. 1994. Ecology of alpine streams. Freshw. Biol. 32:277-294.

Wehr, J. D., Sheath, R. G. \& Kociolek, J. P. 2015. Freshwater algae of North America: ecology and classification. 2nd ed. Academic Press/Elsevier, San Diego, CA, 1050 pp. 